\title{
Exogenous factors as potential antiplatelet drugs
}

Citation for published version (APA):

van den Kerkhof, D. (2021). Exogenous factors as potential antiplatelet drugs. [Doctoral Thesis, Maastricht University]. Maastricht University. https://doi.org/10.26481/dis.20210708dk

Document status and date:

Published: 01/01/2021

DOI:

$10.26481 /$ dis.20210708dk

Document Version:

Publisher's PDF, also known as Version of record

\section{Please check the document version of this publication:}

- A submitted manuscript is the version of the article upon submission and before peer-review. There can be important differences between the submitted version and the official published version of record.

People interested in the research are advised to contact the author for the final version of the publication, or visit the DOI to the publisher's website.

- The final author version and the galley proof are versions of the publication after peer review.

- The final published version features the final layout of the paper including the volume, issue and page numbers.

Link to publication

\footnotetext{
General rights rights.

- You may freely distribute the URL identifying the publication in the public portal. please follow below link for the End User Agreement:

www.umlib.nl/taverne-license

Take down policy

If you believe that this document breaches copyright please contact us at:

repository@maastrichtuniversity.nl

providing details and we will investigate your claim.
}

Copyright and moral rights for the publications made accessible in the public portal are retained by the authors and/or other copyright owners and it is a condition of accessing publications that users recognise and abide by the legal requirements associated with these

- Users may download and print one copy of any publication from the public portal for the purpose of private study or research.

- You may not further distribute the material or use it for any profit-making activity or commercial gain

If the publication is distributed under the terms of Article $25 \mathrm{fa}$ of the Dutch Copyright Act, indicated by the "Taverne" license above, 
Summary 


\section{Summary}

This thesis has aimed at lessons from nature for drug development. Exogenic proteins related to platelet inhibition via $\alpha \operatorname{IIb} \beta 3$ were produced and their potential antiplatelet effects were investigated.

Chapter 1 provides a brief introduction about hemostasis, regulatory mechanisms, thrombosis, bleeding, and the laboratory tests that have been used in this thesis. When hemostasis is disturbed upon injury of the vessel wall, blood platelets adhere and coagulation is initiated which eventually leads to fibrin formation. These processes are suppressed in healthy vessels by natural anticoagulants. In case of impaired hemostasis, either thrombosis or bleeding will occur. The main laboratory tests that have been used in this thesis, light transmission aggregometry and whole blood thrombus formation under flow, are introduced briefly.

This chapter also describes peptide drugs and exogenous proteins that are currently used in the clinic. Peptides and proteins that have been used to unravel molecular mechanisms in health and disease are also briefly introduced.

Chapter 2 gives an overview of the integrin $\alpha \operatorname{Ilb} \beta 3$, its signaling pathways, oral antagonists, binding of the currently used antiplatelet drugs abciximab, tirofiban and eptifibatide, and peptides and proteins derived from nature that play a role in modulating platelet aggregation. In this chapter, we focused on disintegrins, which are low molecular weight integrin-binding cysteine-rich peptides that bind to the $\alpha \mathrm{IIb} \beta 3$ integrin. This resulted in an overview of 73 disintegrins found in snakes, ticks, leeches, worms and horseflies, that affect mainly the $\alpha \operatorname{IIb} \beta 3$ integrin on platelets. However, some disintegrins also target $\alpha v \beta 3, \alpha 5 \beta 1, \alpha 2 \beta 1$ or $\alpha v \beta 5$ integrins.

In Chapter 3, the effects of two tick-derived proteins, disagregin and RGDdisagregin, on platelet adhesion, thrombus formation and fibrin formation were 
described. The two proteins were chemically synthesized and tested in platelet aggregation tests. Disagregin inhibited ADP- and collagen-induced platelet aggregation with $\mathrm{IC}_{50}$ values of $99 \mathrm{nM}$ and $64 \mathrm{nM}$, respectively. For further experiments, two concentrations were chosen $\left(100 \mathrm{nM}, \sim \mathrm{IC}_{50}\right.$ and $\left.1 \mu \mathrm{M}, \sim 10 \mathrm{x} \mathrm{IC}_{50}\right)$. The $1 \mu \mathrm{M}$ concentration of disagregin and RGD-disagregin significantly inhibited platelet aggregation induced with ADP or collagen. The $100 \mathrm{nM}$ concentration of RGD-disagregin significantly reduced collagen-induced platelet aggregation, while $100 \mathrm{nM}$ of disagregin did not. Whole blood platelet aggregation and thrombus formation under flow with disagregin or RGD-disagregin resulted in the suppression of multilayered and contracted thrombi, showing only single platelet adhesion. Integrin activation was also decreased by the addition of disagregin or RGD-disagregin.

Flow-dependent thrombus formation was assessed in the presence of coagulation triggered by TF. In the presence of $1 \mu \mathrm{M}$ disagregin or RGD-disagregin, only single platelets adhered, which did not aggregate or displayed PS exposure or fibrin formation, while control samples showed large aggregates, massive PS exposure and fibrin formation. Time to fibrin formation was significantly delayed by the addition of disagregin of RGD-disagregin from 5 to 12-13 minutes. Disagregin and RGD-disagregin are potential $\alpha \mathrm{IIb} \beta 3$ integrin inhibitors because of their inhibition pattern on platelet adhesion, aggregation and fibrin formation.

Chapter 4 focuses on the importance of the homoarginine residue in antiplatelet drug eptifibatide in binding to the $\alpha \operatorname{Ilb} \beta 3$ integrin. Eptifibatide analogs, containing an Arg or Lys residue at the position of the hArg residue, were synthesized by solid-phase peptide synthesis. Light transmission aggregometry was performed and resulted in $\mathrm{IC}_{50}$ values for eptifibatide of $0.38 \mu \mathrm{M}$ and $0.27 \mu \mathrm{M}$ for ADP- and

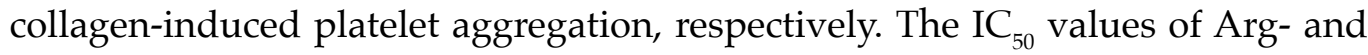


Lys-eptifibatide were 7-9 times higher by ADP-stimulated platelet aggregation and 6-8 times higher by collagen-stimulated platelet aggregation. Pre-incubation with Arg- or Lys-eptifibatide did not affect platelet aggregation. Collagen/TFinduced whole blood thrombus formation was performed and resulted in the formation of large aggregates by the addition of Arg- or Lys-eptifibatide, as also indicated by the control samples, while eptifibatide showed small aggregate formation.

The time to fibrin formation was delayed by the addition of eptifibatide, while time to first fibrin formation of the analogs was comparable to control. In flow cytometry experiments, washed platelets were activated with CRP-XL, ADP or TRAP-6 to investigate the effects of eptifibatide, Arg- or Lys-eptifibatide on platelet activation. PAC1 binding was decreased by the addition of eptifibatide when activated with CRP-XL or ADP, while the addition of the analogs showed no significant effects in PAC1 binding. Molecular dynamics simulations revealed that the mutation of the hArg to Arg or Lys resulted in losing $\alpha \mathrm{Ill} b$ domain interactions, thereby confirming that the hArg in eptifibatide is essential for effective binding to the $\alpha \operatorname{Ilb} \beta 3$ integrin.

In Chapter 5 we unraveled the structure of disagregin using solution NMR spectroscopy. Binding of disagregin to the $\alpha \mathrm{IIb} \beta 3$ integrin was investigated by a fluorescence polarization assay. Flow cytometry experiments showed that pre-incubation with disagregin prevented PAC1 binding and partly prevented AF647-fibrinogen binding, explained by the additional binding sites of fibrinogen for the $\alpha \operatorname{IIb} \beta 3$ integrin complex. Post-incubation with disagregin did not replace the binding of high-affinity PAC1 or AF647-fibrinogen.

Chapter 6 studies the effects of tick salivary protein savignygrin on platelet aggregation and its binding to the $\alpha \operatorname{Ilb} \beta 3$ integrin by molecular dynamics 
simulations. A dose-dependent effect of savignygrin was shown in both ADPand collagen-induced platelet aggregation, resulting in $\mathrm{IC}_{50}$ values of $366 \mathrm{nM}$ and $165 \mathrm{nM}$ for ADP- and collagen-induced platelet aggregation, respectively.

From molecular dynamics simulation studies, it appeared that savignygrin could not fit well into the binding pocket of $\alpha \operatorname{Ilb} \beta 3$, because several hydrogen bonds could not be formed. The binding of savignygrin to the $\alpha \mathrm{IIb} \beta 3$ integrin was compared to the binding of disagregin, resulting in a significantly higher (less negative) binding free energy value for savignygrin, indicating that disagregin can bind to $\alpha \operatorname{Ilb} \beta 3$ stronger than savignygrin. This can be explained by the fact that the glycine residue of the RGD motif in savignygrin does not show strong interactions with surrounding residues of $\alpha \operatorname{IIb} \beta 3$.

The final Chapter 7 discusses the main findings of this thesis and elaborates the potential clinical relevance of these in view of the current literature. The studies presented in this thesis provide new insights into peptides and proteins derived from nature, new sequences that also bind to the $\alpha \operatorname{IIb} \beta 3$ integrin, the importance of homoarginine in the clinically used antiplatelet drug eptifibatide, structure-activity relationships between disagregin and the $\alpha \operatorname{IIb} \beta 3$ integrin and the antiplatelet effects of savignygrin and its binding to the $\alpha \mathrm{IIb} \beta 3$ integrin. 

Samenvatting 


\section{Samenvatting}

Als de hemostase verstoord raakt door schade aan de wand van een bloedvat, dan worden de bloedplaatjes geactiveerd en bloedstolling geïnitieerd, wat uiteindelijk zal leiden tot fibrinevorming. Deze processen worden in gezonde bloedvaten onderdrukt door aanwezige antistollingsmechanismen. Als de hemostase verstoord is kan dit leiden tot trombose of bloedingen.

Hoofdstuk 1 geeft een korte introductie over hemostase, regulerende mechanismen, trombose en bloedingen. De laboratoriumtesten die uitgevoerd zijn in deze dissertatie, bloedplaatjesaggregatie en trombusvorming in stromend volbloed, worden kort geïntroduceerd in dit hoofdstuk. Verder beschrijft dit hoofdstuk ook peptiden en exogene eiwitten die op dit moment gebruikt worden als medicijn in de kliniek. Daarnaast worden ook peptiden en eiwitten geïntroduceerd die gebruikt zijn om moleculaire mechanismen te ontrafelen, in zowel fysiologische en pathologische processen.

Hoofdstuk 2 geeft een overzicht van de $\alpha \operatorname{IIb} \beta 3$ integrine receptor, signaleringsroutes, orale antagonisten, binding van abciximab, tirofiban en eptifibatide aan de $\alpha \operatorname{IIb} \beta 3$ receptor, en peptiden en eiwitten uit de natuur die een rol spelen in bloedplaatjesaggregatie. In dit hoofdstuk focussen we op disintegrines. Disintegrines zijn laagmoleculaire en cysteïne-rijke peptiden die binden aan de $\alpha \Pi b \beta 3$ receptor. We geven een overzicht van 73 disintegrines uit slangen, teken, bloedzuigers, wormen en paardenvliegen, die vooral een effect op de $\alpha \operatorname{Ilb} \beta 3$ receptor in bloedplaatjes hebben. Sommige disintegrines hebben ook een effect op de $\alpha v \beta 3, \alpha 5 \beta 1, \alpha 2 \beta 1$ of $\alpha v \beta 5$ receptor.

In Hoofdstuk 3 worden de effecten van twee tekeneiwitten, disagregine en RGD-disagregine, op bloedplaatjesadhesie, trombus- en fibrinevorming besproken. Deze twee eiwitten werden chemisch gesynthetiseerd en getest in 
bloed plaatjesaggregatietesten. Disagregine remt ADP- en collageen-geïnduceerde bloedplaatjesaggregatie met $\mathrm{IC}_{50}$-waarden van $99 \mathrm{nM}$ en $64 \mathrm{nM}$. Voor verdere experimenten werden twee concentraties gekozen $\left(100 \mathrm{nM}, \mathrm{IC}_{50}\right.$ en $1 \mu \mathrm{M}, \sim 10 \mathrm{x}$ $\mathrm{IC}_{50}$ ). De hoge concentratie van disagregine en RGD-disagregine verminderde significant de ADP- en collageen-geïnduceerde bloedplaatjesaggregatie. De lage concentratie (100 $\mathrm{nM})$ van RGD-disagregine verminderde significant de collageen-geïnduceerde bloedplaatjesaggregatie, terwijl de lage concentratie van disagregine geen effect had. Bloedplaatjesaggregatie en trombusvorming in stromend volbloed met disagregine of RGD-disagregine resulteerde in de aanhechting van losse bloedplaatjes, waarbij geen gecontraheerde trombi werden gevormd. Door het toevoegen van disagregine of RGD-disagregine verminderde ook de integrine activatie.

Trombusvorming in stromend volbloed werd uitgevoerd in de aanwezigheid van stolling veroorzaakt door weefselfactor. Losse bloedplaatjes hechtten aan in de aanwezigheid van $1 \mu \mathrm{M}$ disagregine of RGD-disagregine. Deze bloedplaatjes vormden geen aggregaten, brachten geen fosfatidylserine totexpressieen vormden geen fibrine. In controlemetingen werden grote aggregaten gevormd, werd veel fosfatidylserine tot expressie gebracht en werd veel fibrine gevormd. De tijd tot fibrinevorming was vertraagd van 5 naar 12-13 minuten door het toevoegen van disagregine of RGD-disagregine. Disagregine en RGD-disagregine zijn potentiële kandidaten voor de remming van de $\alpha \mathrm{IIb} \beta 3$ receptor vanwege hun effecten op bloedplaatjesadhesie, bloedplaatjesaggregatie en fibrinevorming.

Hoofdstuk 4 focust op het belang van het aminozuur homoarginine (hArg) dat aanwezig is in de bloedplaatjesaggregatieremmer eptifibatide. Analoga, die een arginine of lysine aminozuur op de positie van het homoarginine residu hebben, werden gesynthetiseerd met behulp van vaste-fase peptidensynthese. 
Bloedplaatjesaggregatietesten werden uitgevoerd en resulteerden in de volgende $\mathrm{IC}_{50}$-waarden voor eptifibatide; $0.38 \mu \mathrm{M}$ voor ADP-geïnduceerde aggregatie en

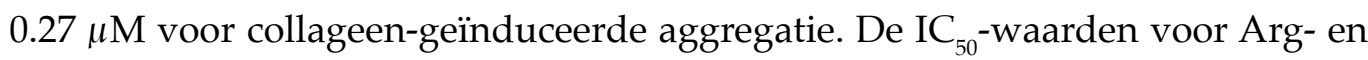
Lys-eptifibatide waren 7-9 keer hoger voor ADP-geïnduceerde aggregatie en 6-8 keer hoger voor collageen-geïnduceerde aggregatie. Pre-incubatie met Arg- of Lys-eptifibatide leidde niet tot een effect op de bloedplaatjesaggregatie. Volbloed collageen/weefselfactor-geïnduceerde trombusvorming werd uitgevoerd en resulteerde in grote aggregaten door toevoeging van Arg- en Lys-eptifibatide, vergelijkbaar met de controlesamples, terwijl de toevoeging van eptifibatide tot de vorming van kleine aggregaten leidde. De tijd tot fibrinevorming was vertraagd door het toevoegen van eptifibatide, terwijl de toevoeging van Arg- of Lys-eptifibatide niet resulteerde in een vertraging.

Gewassen bloedplaatjes zijn in flowcytometrie experimenten geactiveerd met CRP-XL, ADP of TRAP-6 om de effecten van eptifibatide, Arg- of Lys-eptifibatide op bloedplaatjesactivatie te onderzoeken. PAC1 binding door activatie met CRP-XL of ADP was afgenomen door het toevoegen van eptifibatide, terwijl het toevoegen van de analoga geen effect had op de PAC1 binding. Molecular dynamics simulaties toonden aan dat de wisseling van homoarginine voor arginine of lysine resulteerde in minder interacties met het $\alpha \mathrm{IIb}$ domein van de receptor. Hierdoor kunnen we concluderen dat het aminozuur hArg in eptifibatide essentieel is voor effectieve binding aan de $\alpha \mathrm{IIb} \beta 3$ receptor.

In Hoofdstuk 5 hebben we de structuur van disagregine opgehelderd met behulp van NMR-spectroscopie. Verder werd door middel van een fluorescentie polarisatie test de binding van disagregine aan de $\alpha \operatorname{Ilb} \beta 3$ integrine receptor onderzocht. Pre-incubatie met disagregine leidde tot suppressie van PAC1 binding aan de geactiveerde $\alpha \mathrm{IIb} \beta 3$ receptor op bloedplaatjes. Daarnaast werd 
ook gedeeltelijk, vanwege de additionele bindingsplekken van fibrinogeen, de AF647-fibrinogeen binding geremd. Post-incubatie met disagregine veranderde de binding van PAC1 of AF647-fibrinogeen niet.

Hoofdstuk 6 beschrijft de effecten van het tekeneiwit savignygrine op bloedplaatjesaggregatie en de binding van savignygrine aan de $\alpha \operatorname{IIb} \beta 3$ integrine receptor met behulp van molecular dynamics simulaties. Een dosisafhankelijk effect van savignygrine was zichtbaar in ADP- en collageen-geïnduceerde aggregatie, dat resulteerde in $\mathrm{IC}_{50}$-waarden van $366 \mathrm{nM}$ (ADP) and $165 \mathrm{nM}$ (collageen). Molecular dynamics simulaties lieten zien dat savignygrine niet goed kon binden aan de $\alpha \mathrm{IIb} \beta 3$ receptor aangezien enkele enkele essentiële interacties niet gevormd konden worden. De binding van savignygrine aan de $\alpha \operatorname{IIb} \beta 3$ receptor werd vergeleken met de receptorbinding van disagregine. De bindingsvrije energiewaarde van savignygrine was significant hoger (minder negatief) dan de bindingsvrije energiewaarde van disagregine, wat aangeeft dat disagregine sterker aan de $\alpha \operatorname{Ilb} \beta 3$ receptor bindt dan savignygrine. Dit komt doordat het aminozuur glycine van savignygrine geen sterke interacties maakt met de omringende aminozuren van de $\alpha \operatorname{Ilb} \beta 3$ receptor.

Hoofdstuk 7 bediscussieert de belangrijkste bevindingen van dit proefschrift en de potentiële klinische relevantie. De studies in dit proefschrift geven nieuwe inzichten in peptiden en eiwitten uit de natuur, nieuwe sequenties die binden aan de $\alpha \operatorname{Ilb} \beta 3$ receptor, het belang van het aminozuur homoarginine in de bloedplaatjesaggregatieremmer eptifibatide, structuur-activiteit relaties tussen disagregine en de $\alpha \mathrm{IIb} \beta 3$ receptor, de effecten van savignygrine op bloedplaatjes en de binding van savignygrine aan de $\alpha \operatorname{IIb} \beta 3$ receptor. 